corticotrophin, and whose plasma cortisol was well above normal and still rising. Post-operative collapse is very rarely associated with a low plasma cortisol: those few cases in which normal corticotrophin production is not restored will be diagnosed in the few days after steroid-weaning, when hypoadrenal collapse presents a medical emergency.

Evidence of later failure of the stress response is remarkably scanty, however. Although the assay of plasma corticosteroids has been possible for more than 10 years, recorded low values with post-steroid-therapy collapse are disappointingly rare: the only authenticated example was reported by Sampson et al. (1961). This remarkable lack of data on a widely suspected phenomenon makes one ponder in an age eager to apply every new scientific advance. It is a challenge to present-day clinicians to obtain unequivocal evidence when opportunity presents. Until this is properly done its frequence must remain a matter of speculation. But the lack of evidence after at least five years' search implies that it is a great rarity.

The fundamental requirements are the demonstration of low or normal plasma-cortisol levels during severe stress in a subject who had normal adrenal function before steroid therapy, because unsuspected cases of Addison's disease may be revealed by their inadequate reaction to stress, and in these failure of the stress response clearly cannot be imputed to steroid therapy. We still eagerly await evidence that adrenal failure of stress response is a significant risk after steroid therapy.

[Part II, with a list of references, will appear in our next issue.]

\title{
Immunosuppressive Therapy in Steroid-resistant Proliferative Glomerulonephritis Accompanied by the Nephrotic Syndrome
}

\author{
R. H. R. WHITE,* M.A., M.B., M.R.C.P., D.C.H. ; J. S. CAMERON, † M.D., B.SC., M.R.C.P. \\ J. R. TROUNCE, $\ddagger$ M.D., F.R.C.P.
}

[With Special Plate]

Erit. med. F., 1966, 2, 853-860

Corticosteroid therapy is well established in the management of the nephrotic syndrome due to primary renal disease. Its use has led to increased survival both in children (Riley and Scaglione, 1959 ; Arneil, 1961) and in adults (Hardwicke, 1965a), and to the achievement of more rapid relief from oedema, especially in children. However, with the objective sign of disappearance of proteinuria as the criterion of complete remission, about $85 \%$ of adults (Blainey et al., 1960 ; Pearl et al., 1964) and $36 \%$ of children (Arneil, 1961) ultimately fail to respond to steroids. The difference between adults and children is largely explained by the frequent histological finding in children of " minimal change." Steroid-resistant patients form a high proportion of cases referred to special clinics, and most of them are severely ill; we find that the majority of adults and children in this group have proliferative glomerulonephritis.

In this paper we describe our early experiences with immunosuppressive therapy in a group of 18 nephrotic patients suffering from proliferative glomerulonephritis. The literature on the use of immunosuppressant agents is summarized in Table I, from which it can be seen that mechlorethamine (nitrogen mustard) had been used in the pre-steroid era (Chasis et al., 1949, 1950 ; Taylor et al., 1950 ; Kelley and Panos, 1952). However, with the advent of prednisolone the pattern of therapeutic response improved so dramatically in children (Arneil, 1961) that the demand for more toxic drugs was no longer felt. Nevertheless, the literature contains occasional reports of the combined use of steroids and mechlorethamine in treating nephrotic children (Lestina et al., 1953 ; Greenman et al., 1955 ; West, 1958 ; Coldbeck, 1963), but the results were not convincingly better than those of steroid therapy alone.

More recently interest in the use of immunosuppressant agents has revived owing to the recognition of steroid-resistant

* Senior Lecturer in Paediatrics and Child Health, University of Birmingham; lately Assistant to the Director, Department of Paediatrics, Guy's Hospital Medical School, London.

† Senior Lecturer in Medicine, Guy's Hospital Medical School, London.

t Professor of Clinical Pharmacology, Guy's Hospital Medical School, London. forms of the nephrotic syndrome (Lagrue et al., 1962, 1964 ; Goodman et al., 1963 ; Talamo and Crawford, 1963 ; Payet et al., 1964 ; Drummond et al., 1964 ; Shearn, 1965 ; Milliez et al., 1965 ; Saxina and Crawford, 1965 ; West et al., 1965b, 1966), and the accumulation of evidence that immune mechanisms are involved in certain forms of glomerulonephritis (Peters, 1963 ; Michael et al., 1964). At the same time less toxic orally administered drugs became available. These drugs have also been used with some success in other disorders in which immune mechanisms are believed to be involved, especially systemic lupus erythematosus (Kellum and Haserick, 1963 ; Demis et al., 1964 ; Hill and Scott, 1964 ; Cheng Siang et al., 1966).

\section{Material and Methods}

All 18 patients developed, either initially or during the course of their illness, the nephrotic syndrome, which for the purpose of this paper is defined as heavy proteinuria and hypoalbuminaemia, at some time accompanied by oedema. Fifteen had previously been treated with prednisolone in adequate dosage, and three children had also received other steroids (dexamethasone, triamcinolone, and A.C.T.H.) on account of a poor therapeutic response. All 15 had persistent proteinuria despite steroid therapy, and 13 continued to have hypoalbuminaemia with oedema. Seven children were severely cushingoid and five patients (Cases 6, 10,11, 15, and 17) developed signs of increasing renal insufficiency while on high doses of corticosteroids. One patient (Case 4) also had steroid diabetes.

The main clinical and laboratory findings are summarized in Table II, in which the patients are arranged in order of age. There were 13 children under 15 years old and five adults, the age at onset of symptoms ranging from 5 weeks to 71 years. Six children and one adult also had anaphylactoid purpura. The antistreptolysin-O titre was considerably raised in four children and two adults. Significant hypertension occurred in 14 patients, the figures of Haggerty et al. (1956) being used as a reference for children. In addition to protein an excess of red blood cells, as measured by 12-hour Addis counts, was 
present in the urine of all patients, and in nine the urine was visibly blood-stained.

\section{Selectivity of Proteinuria}

Urinary protein clearances were determined immunochemically in 17 patients before treatment, and serially in those who survived with residual proteinuria, the modification of Soothill's (1962) method previously described (Joachim et al., 1964 ; Cameron and White, 1965) being used. The initial findings are given in Table II and are expressed as the angle $(\theta)$ formed with the horizontal by the regression line of $\log \mathrm{U} / \mathrm{P}$ against $\log$ molecular weight of five to seven individual plasma proteins.

TABLE I.-Summary of the Literature on Immunosuppressive Therapy in the Nephrotic Syndrome, 1949-66

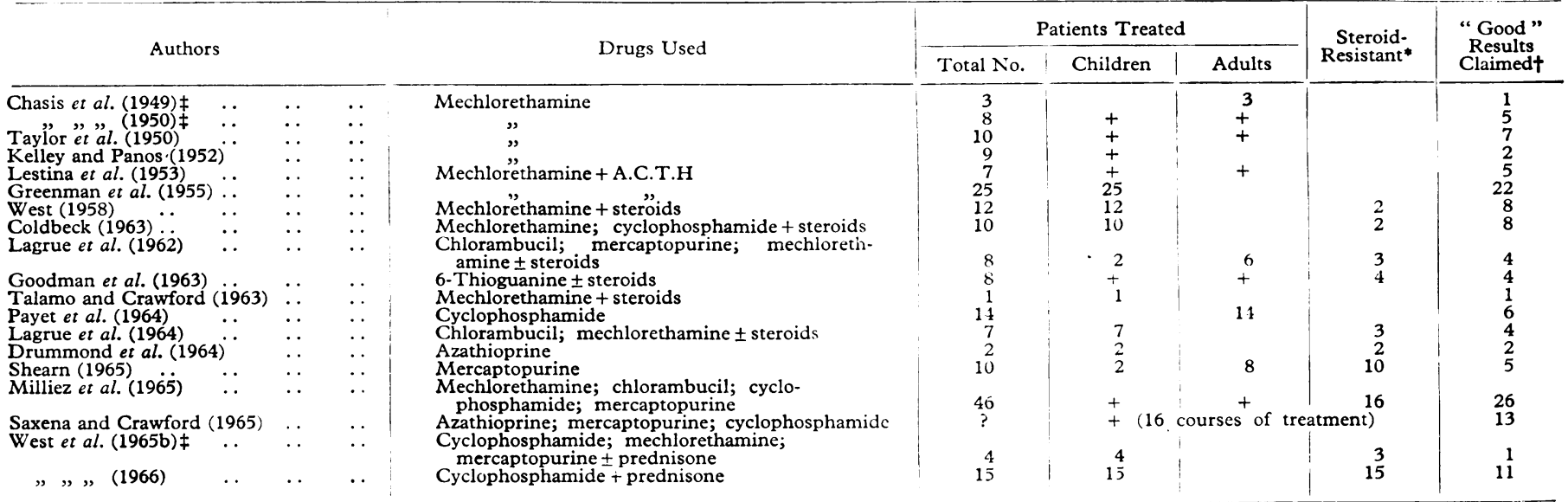

* The term "steroid-resistant" here includes patients who relapse frequently or have residual proteinuria, as well as those showing no response at all.

† Authors have given varying amounts of data, but a " good" response generally means clinical improvement with reduction or disappearance of proteinuria. $\ddagger$ Patients without nephrotic syndrome included in series.

TABLE II.-Clinical and Laboratory Findings in the 18 Patients*

\begin{tabular}{|c|c|c|c|c|c|c|c|c|c|c|c|c|c|}
\hline \multirow{2}{*}{$\begin{array}{l}\text { Case } \\
\text { No. }\end{array}$} & \multirow{2}{*}{ Sex } & \multirow{2}{*}{\multicolumn{2}{|c|}{$\begin{array}{c}\text { Age at } \\
\text { Onset } \\
\text { (yrs. mths.) }\end{array}$}} & \multirow{2}{*}{ Oedema } & \multirow{2}{*}{$\begin{array}{l}\text { Hyper- } \\
\text { tension } \\
(\mathrm{mm} . \mathrm{Hg})\end{array}$} & \multirow{2}{*}{$\begin{array}{c}\text { Haema- } \\
\text { turiat }\end{array}$} & \multirow{2}{*}{$\begin{array}{c}\text { Blood Urea } \\
\text { (mg.l } \\
100 \mathrm{ml} .)\end{array}$} & \multicolumn{2}{|c|}{$\begin{array}{l}\text { Serum Proteins } \\
(\mathrm{g} . / 100 \mathrm{ml} .)\end{array}$} & \multirow{2}{*}{$\underset{\text { (units/mi.) }}{\text { ASOT }}$} & \multirow{2}{*}{$\begin{array}{c}\text { Protein- } \\
\text { uria } \\
\text { Selec- } \\
\text { tivity } \\
\left(0^{\circ}\right)\end{array}$} & \multirow{2}{*}{$\begin{array}{l}\text { Previous Steroid } \\
\text { Response }\end{array}$} & \multirow{2}{*}{ Additional Features } \\
\hline & & & & & & & & Total & Albumin & & & & \\
\hline 1 & $\mathbf{M}$ & Birt & & & $\begin{array}{l}0 \\
0\end{array}$ & $\begin{array}{l}\mathrm{m} \\
\mathrm{m}\end{array}$ & $\begin{array}{l}16 \\
20\end{array}$ & $\begin{array}{l}3.9 \\
2.5\end{array}$ & $\begin{array}{l}0.5 \\
1.7\end{array}$ & $\overline{-}$ & $\overline{63}\}$ & Not given & $\begin{array}{l}\text { Congenital nephrotic; } \\
2 \text { previously affected } \\
\text { siblings died }\end{array}$ \\
\hline 2 & $\mathrm{~F}$ & 21 & 11 & & $\begin{array}{l}0 \\
0\end{array}$ & $\underset{\mathrm{m}}{\mathrm{M}}$ & $\begin{array}{l}43 \\
16\end{array}$ & $\begin{array}{l}4 \cdot 9 \\
5 \cdot 8\end{array}$ & $\begin{array}{l}1 \cdot 8 \\
3 \cdot 4\end{array}$ & $\begin{array}{l}<50 \\
106\end{array}$ & $\overline{69}\}$ & $\begin{array}{l}\text { Little improvement; } \\
\text { cushingoid }\end{array}$ & Anaphylactoid purpura \\
\hline 3 & $\mathrm{~F}$ & 3 & 2 & & $\begin{array}{l}0 \\
+\end{array}$ & $\underset{\mathrm{m}}{\mathrm{m}}$ & $\begin{array}{l}21 \\
45\end{array}$ & $\begin{array}{l}4 \cdot 7 \\
3 \cdot 2\end{array}$ & $\begin{array}{l}1 \cdot 1 \\
0.9\end{array}$ & E & $\left.\frac{73}{-}\right\}$ & $\begin{array}{l}\text { Deterioration; } \\
\text { hypertension, } \\
\text { melaena }\end{array}$ & $\begin{array}{l}\text { Familial; previously } \\
\text { affected sibling died }\end{array}$ \\
\hline 4 & $\mathrm{~F}$ & 3 & 9 & $\left\{\begin{array}{l}+ \\
+\end{array}\right.$ & $\stackrel{+}{+}$ & $\underset{\mathrm{m}}{\mathrm{0}}$ & $\begin{array}{l}30 \\
23\end{array}$ & $\begin{array}{l}4 \cdot 3 \\
4 \cdot 8\end{array}$ & $\begin{array}{l}2 \cdot 4 \\
2 \cdot 4\end{array}$ & 250 & $\overline{69}$ & $\begin{array}{l}\text { No change; steroid- } \\
\text { induced diabetes; } \\
\text { cushingoid }\end{array}$ & Anaphylactoid purpura \\
\hline 5 & $\mathrm{~F}$ & 6 & 6 & \{ & $\stackrel{+}{0}$ & $\begin{array}{l}\mathrm{M} \\
\mathrm{m}\end{array}$ & $\begin{array}{l}46 \\
26\end{array}$ & $\begin{array}{l}4 \cdot 7 \\
3.9\end{array}$ & $\begin{array}{l}1 \cdot 6 \\
1.7\end{array}$ & $\underline{800}$ & $\overline{47}\}$ & $\begin{array}{l}\text { No change; } \\
\text { cushingoid }\end{array}$ & $"$ \\
\hline 6 & $\mathbf{M}$ & 6 & 9 & \{ & + & $\begin{array}{l}M \\
M\end{array}$ & $\begin{array}{r}35 \\
180\end{array}$ & $\begin{array}{l}4 \cdot 9 \\
3 \cdot 7\end{array}$ & $\begin{array}{l}1.9 \\
1.7\end{array}$ & $\begin{array}{r}50 \\
<50\end{array}$ & $\overline{28}\}$ & $\begin{array}{l}\text { Deterioration; renal } \\
\text { insufficiency }\end{array}$ & $\begin{array}{l}\text { Death from acute } \\
\text { cerebral oedema }\end{array}$ \\
\hline 7 & M & 7 & 0 & \{ & $\begin{array}{l}0 \\
+\end{array}$ & $\underset{\mathrm{m}}{\mathrm{M}}$ & $\begin{array}{l}61 \\
21\end{array}$ & $\begin{array}{l}6 \cdot 4 \\
5 \cdot 2\end{array}$ & $\begin{array}{l}2 \cdot 3 \\
1 \cdot 4\end{array}$ & 166 & $\left.\frac{44}{-}\right\}$ & Deterioration & Anaphylactoid purpura \\
\hline 8 & $\mathbf{M}$ & 8 & 2 & \{ & $\stackrel{+}{+}$ & $\begin{array}{l}\mathbf{M} \\
\mathbf{M}\end{array}$ & $\begin{array}{r}114 \\
32\end{array}$ & $\begin{array}{l}5 \cdot 8 \\
7 \cdot 3\end{array}$ & $\begin{array}{l}1 \cdot 6 \\
3.7\end{array}$ & 650 & $\overline{58}$ & $\begin{array}{l}\text { Clinical improve- } \\
\text { ment; persistent } \\
\text { proteinuria and } \\
\text { haematuria }\end{array}$ & " \\
\hline 9 & $\mathbf{F}$ & 10 & 4 & $\{+$ & $\begin{array}{l}0 \\
+\end{array}$ & $\underset{\mathrm{m}}{\mathrm{M}}$ & $\begin{array}{l}26 \\
26\end{array}$ & $\begin{array}{l}3 \cdot 7 \\
5 \cdot 3\end{array}$ & $\begin{array}{l}2 \cdot 6 \\
2 \cdot 0\end{array}$ & $<50$ & $\overline{65}\}$ & No change & \\
\hline 10 & $\mathrm{~F}$ & 11 & 7 & $\{+$ & $\stackrel{+}{+}$ & $\underset{\mathrm{m}}{\mathrm{m}}$ & $\begin{array}{r}34 \\
256\end{array}$ & $\begin{array}{l}4 \cdot 6 \\
5 \cdot 0\end{array}$ & $\begin{array}{l}1.6 \\
1.9\end{array}$ & $\begin{array}{l}720 \\
770\end{array}$ & $\overline{66}\}$ & $\begin{array}{l}\text { Deterioration; renal } \\
\text { insufficiency; } \\
\text { cushingoid }\end{array}$ & $\begin{array}{l}\text { Massive terminal } \\
\text { haematemesis- } \\
\text { ? steroid-induced } \\
\text { ulceration }\end{array}$ \\
\hline 11 & $\mathbf{F}$ & 12 & 2 & & $\begin{array}{l}0 \\
+\end{array}$ & $\underset{\mathrm{m}}{\mathrm{m}}$ & $\begin{array}{r}33 \\
128\end{array}$ & $\begin{array}{l}2 \cdot 6 \\
4 \cdot 1\end{array}$ & $\begin{array}{c}\text { "Reduced" } \\
2 \cdot 3\end{array}$ & $<\overline{50}$ & $\overline{59}\}$ & " $\quad$ " & \\
\hline 12 & $\mathbf{M}$ & 13 & 6 & $\{0$ & $\stackrel{+}{+}$ & $\begin{array}{l}\mathrm{M} \\
\mathbf{M}\end{array}$ & $\begin{array}{r}140 \\
60\end{array}$ & $\begin{array}{l}4 \cdot 3 \\
7 \cdot 1\end{array}$ & $\begin{array}{l}1.6 \\
3.3\end{array}$ & $\begin{array}{r}171 \\
>800\end{array}$ & $=\}$ & $\begin{array}{l}\text { Clinical improve- } \\
\text { ment; persistent } \\
\text { proteinuria and } \\
\text { haematuria }\end{array}$ & Anaphylactoid purpura \\
\hline 13 & $\mathbf{F}$ & 14 & & & $\begin{array}{l}0 \\
+\end{array}$ & $\begin{array}{c}\mathrm{m} \\
0\end{array}$ & “ Normal " & $\begin{array}{l}4 \cdot 8 \\
4 \cdot 1\end{array}$ & $\underset{2 \cdot 7}{\text { Reduced " }}$ & $\overline{50}$ & $\overline{35}\}$ & $\begin{array}{l}\text { No change; } \\
\text { cushingoid }\end{array}$ & \\
\hline 14 & $\mathbf{M}$ & 17 & & $\{+$ & + & $\begin{array}{l}M \\
\mathrm{~m}\end{array}$ & $\begin{array}{l}32 \\
40\end{array}$ & $\overline{3 \cdot 9}$ & $\overline{1 \cdot 0}$ & 600 & $\overline{54}\}$ & Not given & \\
\hline 15 & $\mathbf{F}$ & 21 & & & $\begin{array}{l}+ \\
+\end{array}$ & $\begin{array}{l}\mathrm{m} \\
\mathrm{m}\end{array}$ & $\begin{array}{r}50 \\
110\end{array}$ & $\begin{array}{l}3 \cdot 3 \\
3 \cdot 9\end{array}$ & $\begin{array}{l}1.0 \\
1.6\end{array}$ & 二 & $\overline{48}\}$ & $\begin{array}{l}\text { Deterioration; rena! } \\
\text { insufficiency; } \\
\text { cushingoid }\end{array}$ & \\
\hline 16 & $\mathbf{M}$ & 26 & & + & + & M & 240 & $4 \cdot 4$ & $1 \cdot 0$ & 800 & 53 & Not given & $\begin{array}{l}\text { Onset with acute renal } \\
\text { failure, survived } \\
\text { dialysis }\end{array}$ \\
\hline 17 & $\mathbf{F}$ & 44 & & $S+$ & $\begin{array}{l}0 \\
0\end{array}$ & $\underset{\mathrm{m}}{\mathrm{m}}$ & $\begin{array}{r}37 \\
110\end{array}$ & $\begin{array}{l}4 \cdot 2 \\
4 \cdot 5\end{array}$ & $\begin{array}{l}1 \cdot 6 \\
1 \cdot 6\end{array}$ & $\begin{array}{l}250 \\
250\end{array}$ & $\left.\begin{array}{l}62 \\
38\end{array}\right\}$ & $\begin{array}{l}\text { Deterioration; renal } \\
\text { insufficiency }\end{array}$ & $\begin{array}{l}\text { Father died of } \\
\text { nephrotic syndrome }\end{array}$ \\
\hline 18 & $\mathbf{M}$ & 71 & & $\left\{\begin{array}{l}+ \\
+\end{array}\right.$ & $\begin{array}{l}0 \\
0\end{array}$ & $\underset{\mathrm{m}}{\mathrm{m}}$ & $\begin{array}{l}48 \\
52\end{array}$ & $\begin{array}{l}5 \cdot 2 \\
4 \cdot 8\end{array}$ & $\begin{array}{l}2 \cdot 8 \\
2 \cdot 5\end{array}$ & " Normal " & $\left.\frac{64}{-}\right\}$ & $\begin{array}{l}\text { Falling creatinine } \\
\text { clearance }\end{array}$ & \\
\hline
\end{tabular}




\section{Renal Histology}

Renal biopsy was performed on all patients before starting immunosuppressive therapy, and at the time of writing had been repeated in seven patients, with the technique of Kark and Muehrcke (1954), suitably modified (White, 1963) for children. No serious complications have been encountered. Specimens were fixed in $10 \%$ neutral formol-saline, embedded in paraffin and cut at 2-3 $\mu$ thickness. Sections were stained with Meyer's haemalum and eosin (H.E.), and by the periodic-acid-Schiff (P.A.S.) and silver-methenamine (P.A.S.M.) techniques. In addition, post-mortem histology was obtained in three patients in whom renal biopsy had not been repeated.

The main histological findings in the initial and repeat biopsy specimens are summarized in Table III, and illustrated in Figs. 1-12 (Special Plate).

Proliferation of the endothelial cells of the glomerular tufts was present in every case. In Cases $1-4,7,9$, and 18 the proliferation affected the lobular stalks predominantly, although in Cases 2, 7, and 9 occasional glomeruli showed diffuse hypercellularity. The lobular stalks were thickened owing to the deposition of argyrophilic fibrillar material, but the peripheral capillary basement membrane showed little or no abnormality. Capsular epithelial proliferation and adhesions were on the whole slight, except in Cases 7 and 9, where a few crescents were seen. Interstitial oedema and round-cell infiltration, and tubular atrophy were absent in Cases 4 and 7 and patchy in Cases 2 and 3, but were more marked in Case 9. However, Case 1, a congenital nephrotic, showed striking dilatation and reduction in number of the proximal tubules, together with interstitial fibrosis, suggesting "microcystic disease" (Giles et al., 1957).

In the remaining 11 patients endothelial proliferation was mainly diffuse. Capsular epithelial proliferation and adhesions were prominent, eight patients showing numerous crescents, while interstitial changes and tubular atrophy were often widespread. The lobular stalks were considerably expanded owing to extensive argyrophilic fibrillar deposits. All showed capillarywall thickening, which was severe in six patients. In five patients the peripheral basement membranes were thin, sometimes fragmented, and poorly argyrophilic, while the capillary lumina were narrowed or even occluded by deposition, on the endothelial surface of the basement membranes, of eosinophilic material containing a few silver-staining fibrils (Special Plate,
Fig. 8). This appearance has recently been described by West et al. (1965a) in persistent " hypocomplementaemic" glomerulonephritis. In the six other patients, including four with anaphylactoid nephritis, concentric layers of intensely argyrophilic material were deposited on the inner surface of the basement membranes in an irregular manner, so that in areas of greatest endothelial proliferation the capillary walls appeared very thick, while others were hardly affected (Special Plate, Fig. 2). While these two patterns of capillary-wall thickening seem superficially distinct, we have nevertheless observed areas of silver-positive thickening in patients with predominantly non-argyrophilic thickening (notably Case 6), and are at present uncertain how far the appearances can be influenced by variations in staining techniques.

\section{Treatment}

Azathioprine (Imuran) was used in 13 cases and cyclophosphamide (Endoxana) in five. The doses used in individual cases are indicated in Table IV.

Thirteen patients were still receiving steroids at the time of starting immunosuppressive therapy, and these were continued in nine, generally in reduced dosage. In Cases 1, 14, and 16 treatment was begun with azathioprine, and prednisolone was added later.

Most patients were given prophylactic chemotherapy, usually with phenoxymethylpenicillin, although broad-spectrum antibiotics were given temporarily to two who developed agranulocytosis.

Assessment of Results of Treatment.-The clinical condition of the patients was reviewed frequently, with particular emphasis upon the disappearance of oedema and hypertension in those patients in whom they were present at the start of treatment, while observations were made for signs of drug toxicity, such as nausea and vomiting, pallor, purpura, and alopecia. Serial estimations of urinary protein and erythrocyte excretion rates, haemoglobin, erythrocyte sedimentation rate, blood urea, and serum proteins were carried out in all patients. White blood counts were carried out daily initially, and later at weekly intervals. Creatinine and immunochemical urinary protein clearances were measured serially in nine patients, and renal biopsies have so far been repeated in seven patients.

TABLE III.-Summary of Initial and Repeat Renal Biopsy Findings in the 18 Patients*

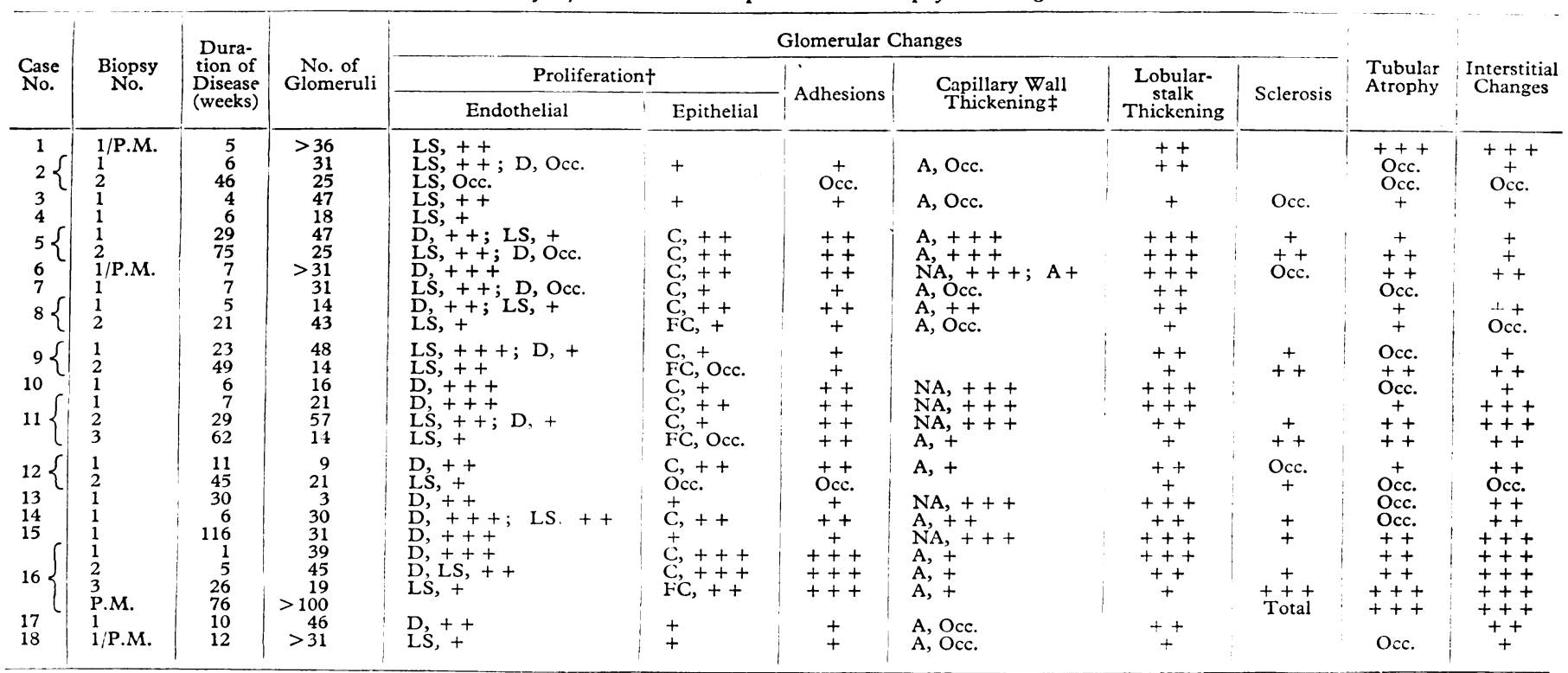


TABLE IV.-Changes in Clinical and Laboratory Findings after Immunosuppressive Therapy

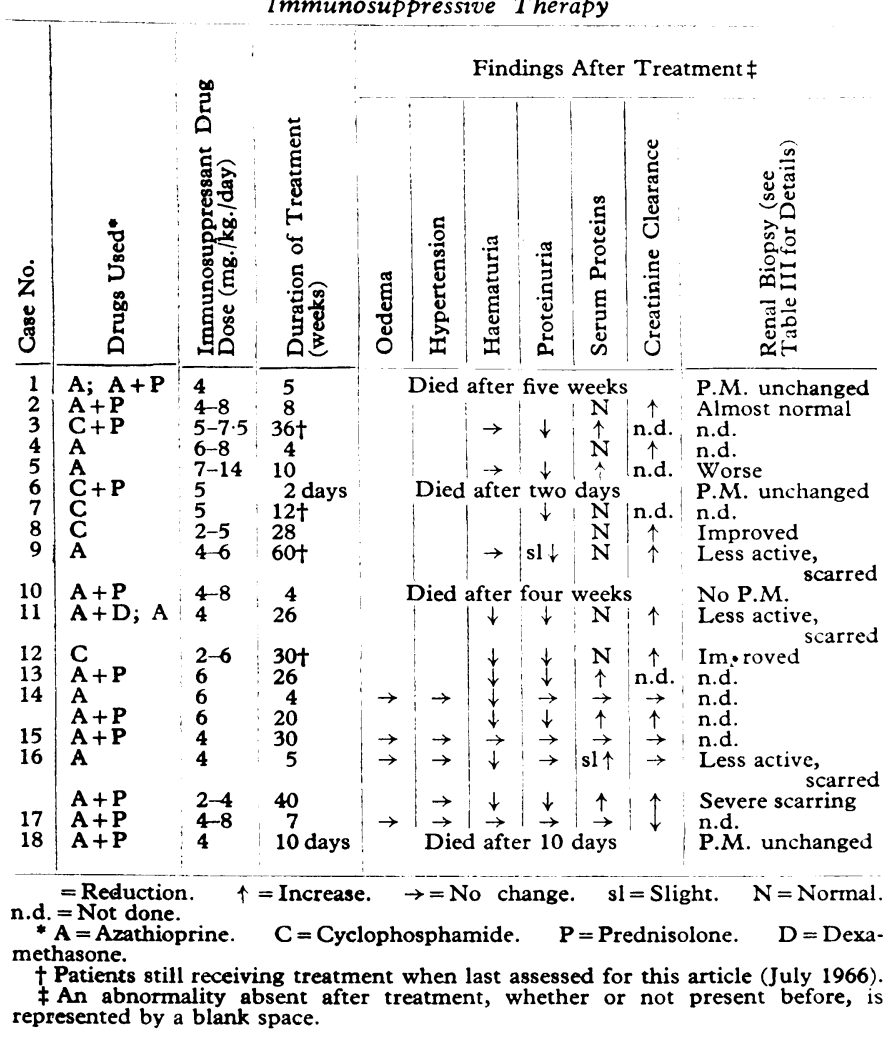

\section{Results}

The results of treatment are summarized in Table IV. Four patients deteriorated despite treatment and died after two days to five weeks :

Case 1.-A congenital nephrotic; two of his siblings had died of a similar condition.

Case 6.- This boy was comatose, convulsing, and had fixed dilated pupils at the time of starting intravenous cyclophosphamide. Acute cerebral oedema, associated with steroid withdrawal, was diagnosed, and, despite the removal of 4 litres of extracellular fluid by peritoneal dialysis, he died; the diagnosis was confirmed at necropsy.

Case 10.-This patient, whose renal biepsy showed extremely severe acute diffuse glomerulonephritis (Special Plate, Figs. 7 and 8) and who had an antistreptolysin-O titre of 770 units/ml., continued to have massive proteinuria and required two intravenous infusions of albumin, both of which were followed by cardiovascular complications. After four weeks of azathioprine treatment she died suddenly following a massive haematemesis. Permission for necropsy was not obtained, but since the platelet count was normal just before death it was thought that she might have had an acute gastric erosion due to sustained high-dosage prednisolone therapy.

Case 18. - This man was grossly oedematous, with large pleural effusions and ascites. During four weeks' treatment with prednisolone, $60 \mathrm{mg} . / \mathrm{day}$, the oedema increased and the creatinine clearance decreased considerably. The addition of azathioprine to steroids in reduced dosage failed to reverse any of the clinical or biochemical abnormalities, and he died in uraemia after a further 10 days.

Of the remaining 14 patients all 10 children showed improvement in both clinical condition and laboratory findings, and three have now entirely lost their proteinuria. Repeat renal biopsies in three patients, including two of those now free from proteinuria, showed undoubted improvement (Table III) ; specimens, obtained from Case 12 before and after six months' therapy are illustrated in Figs. 1-3 (Special Plate). Two patients (Cases 9 and 11) improved both clinically and in renal function. Repeat renal biopsies, obtained after five months' azathioprine treatment, showed an increased proportion of glomerular scarring and sclerosis, with interstitial fibrosis and tubular atrophy, but the unhyalinized glomeruli showed less marked endothelial proliferation (Special Plate, Figs. 4-6), and gave the impression that the disease was becoming less active, having, however, already caused appreciable scarring.

One patient (Case 5), whose first biopsy showed a severe proliferative glomerulonephritis with crescents, lost her oedema and had reduced proteinuria and increased serum albumin after 10 weeks' azathioprine therapy. However, treatment had to be stopped owing to bone-marrow depression, and her proteinuria gradually increased, leading to a return of hypoproteinaemia. A second renal biopsy, obtained 10 months after the first and seven months after the end of specific treatment, showed continuing activity, with total sclerosis of nearly half the glomeruli present.

The results in the four surviving adults were less encouraging. Only two (Cases 14 and 16) improved clinically, showing reduced proteinuria and improved renal function while receiving azathioprine combined with prednisolone, having initially failed to respond to immunosuppressive therapy alone. Case 15, already in chronic renal failure, showed no improvement after 10 months' combined treatment with azathioprine and prednisolone. The treatment of Case 17 was stopped, because or nausea and anaemia, after seven weeks, during which time her blood urea gradually rose from 110 to $130 \mathrm{mg} . / 100 \mathrm{ml}$.

\section{Selectivity of Proteinuria}

Four patients died, and two who improved lost their proteinuria before selectivity determinations had been repeated. Measurements made serially in nine of the remaining 12 patients (Table V) showed no significant deviation from the original figures except in Case 11, who showed an unexplained temporary increase in selectivity.

TABLE V.-Selectivity of Proteinuria Before and After Immunosuppressive Therapy

\begin{tabular}{c|c|c|c}
\hline \multirow{2}{*}{ Case No. } & \multicolumn{2}{|c}{ Selectivity $\left(\theta^{\circ}\right)$} \\
\hline 3 & Result of Treatment & Before & After \\
\hline 5 & Improved & 73 & 72 \\
8 & ” & 47 & 48 \\
9 & "” & 65 & 55 \\
11 & 59 & 71,55 \\
14 & Unchanged & 54 & 43 \\
16 & Improved* & 53 & 53 \\
17 & Unchanged & 38 & 48
\end{tabular}

- Cases 5 and 16 were improving clinically and functionally when immunocemical both deteriorated and one (Case 16) eventually died.

\section{Drug Toxicity}

The side-effects are summarized in Table VI.

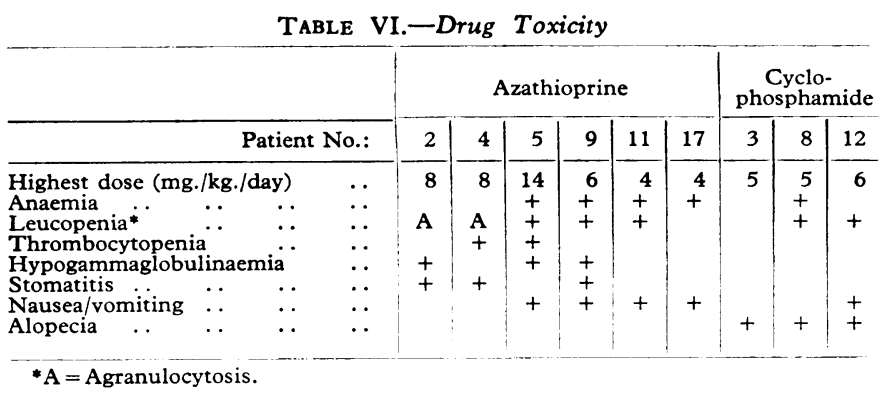

Azathioprine.-Bone-marrow examinations were not carried out, but evidence of depressed activity was seen in six patients. Leucopenia and anaemia were the main effects, and in two children agranulocytosis occurred for several days, together with fever, malaise, and stomatitis. One of them (Case 4), who was severely cushingoid and had steroid diabetes, developed 
symptoms interpreted clinically as signifying acute appendicitis, and was critically ill for a week following laparotomy, at which the only findings were petechial haemorrhages beneath the visceral peritoneum. Anaemia, nausea, and vomiting developed only in patients who had received 10 or more weeks' treatment, and in Cases 2, 5, and 9 there was also a reduction of serum gamma-globulin levels.

Cyclophosphamide.-One patient (Case 6) died after two days' treatment as a result of steroid complications. Three of the remaining four patients developed moderate alopecia, one showed signs of marrow depression, and one experienced nausea.

In all patients with signs of bone-marrow depression, cessation of treatment was followed by restoration of normal function.

\section{Case Reports}

The following case summaries illustrate some of the benefits and hazards of immunosuppressant therapy.

\section{Case 2}

A girl aged 2 years 11 months was admitted to $\mathrm{St}$ George's Hospital, London, under the care of Dr. Ursula James, with typical anaphylactoid purpura accompanied by haematuria. B.P. $105 / 70 \mathrm{~mm}$. $\mathrm{Hg}$, blood urea $43 \mathrm{mg} . / 100 \mathrm{ml}$. Despite bed rest and penicillin her proteinuria increased to $16 \mathrm{~g}$./day and her plasma protein fell to $4.9 \mathrm{~g} . / 100 \mathrm{ml}$. ; albumin $1.8 \mathrm{~g} . / 100 \mathrm{ml}$. Prednisolone, $75 \mathrm{mg}$./day, resulted in a slight rise of plasma proteins (Fig. A), but heavy proteinuria continued and she was transferred to Guy's Hospital. Azathioprine, $4 \mathrm{mg} . / \mathrm{kg}$./day, was started and as there was initially no reduction in proteinuria the dose was increased to 6 and finally $8 \mathrm{mg} . / \mathrm{kg}$./day. Prednisolone was continued in reduced dosage. The quantity of proteinuria diminished, but after three weeks the white blood count showed a substantial fall, accompanied by a reduction in serum proteins. Treatment was stopped, but the W.B.C. continued to fall, reaching a level of $600 / \mathrm{c} . \mathrm{mm}$. (polymorphs 70/c.mm.), which was sustained for one week. During this time she became very ill with fever, rigors, and stomatitis. She made a satisfactory recovery, however, and her proteinuria and haematuria diminished steadily. On attempting to reintroduce azathioprine there was an immediate fall of W.B.C., and it was decided not to proceed with treatment. A repeat renal biopsy, obtained seven months after starting treatment, showed very little

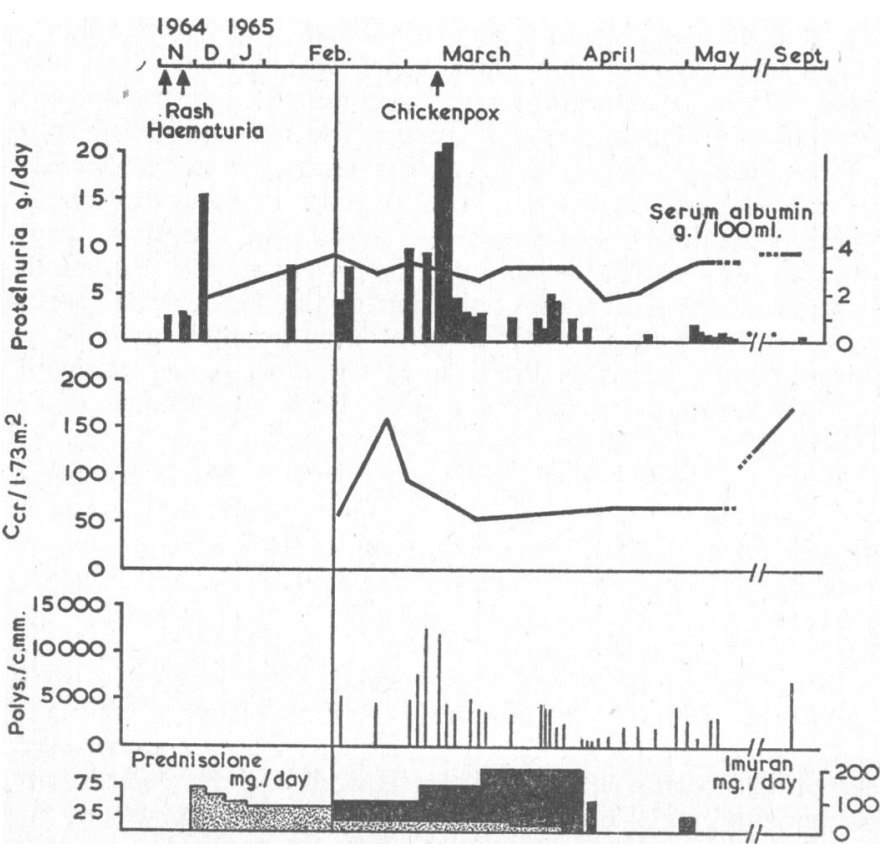

FIG. A.-Treatment and progress of Case 2. abnormality. Three months later she was well, and her urine contained neither protein nor an excess of erythrocytes.

Comment.-This case illustrates apparent benefit after azathioprine therapy, as well as the dangerously low W.B.C. that may result from high dosage.

\section{Case 11}

A girl aged 12 years 2 months was admitted to Dorset County Hospital, under Dr. D. G. Vulliamy, with a typical nephrotic syndrome. B.P. 130/70; urine contained many red blood cells and granular casts. She was treated with prednisolone, $80 \mathrm{mg} . /$ dav, but showed no improvement. Her blood-pressure had risen to $140 / 110$ within two weeks. Treatment was changed to dexamethasone, $10 \mathrm{mg} . /$ day, with A.C.T.H. supplements, but the serum proteins fell and the blood urea rose to $134 \mathrm{mg} . / 100 \mathrm{ml}$. Albumin infusions and hydrochlorothiazide had only a temporary effect, and she was transferred to Guy's Hospital six weeks from onset. She was severely cushingoid and oedematous, with ascitic fluid leaking from aspiration sites, and small bilateral pleural effusions. B.P. $140 / 110 \mathrm{~mm}$. Hg. Urinary protein output $16 \mathrm{~g} . /$ day, Addis count $14,300,000$ R.B.C./12 hours, many granular casts present. She was oliguric and her blood urea was $128 \mathrm{mg} . / 100 \mathrm{ml}$. Renal biopsy (Special Plate, Fig. 4) showed severe proliferative glomerulonephritis with crescents, extensive non-argyrophilic thickening of the capillary walls, and interstitial oedema.

Dexamethasone was continued in reduced dosage and azathioprine, $5 \mathrm{mg} . / \mathrm{kg} . /$ day, was added. Within two weeks there was a substantial fall of blood urea (Fig. B), together with a reduction

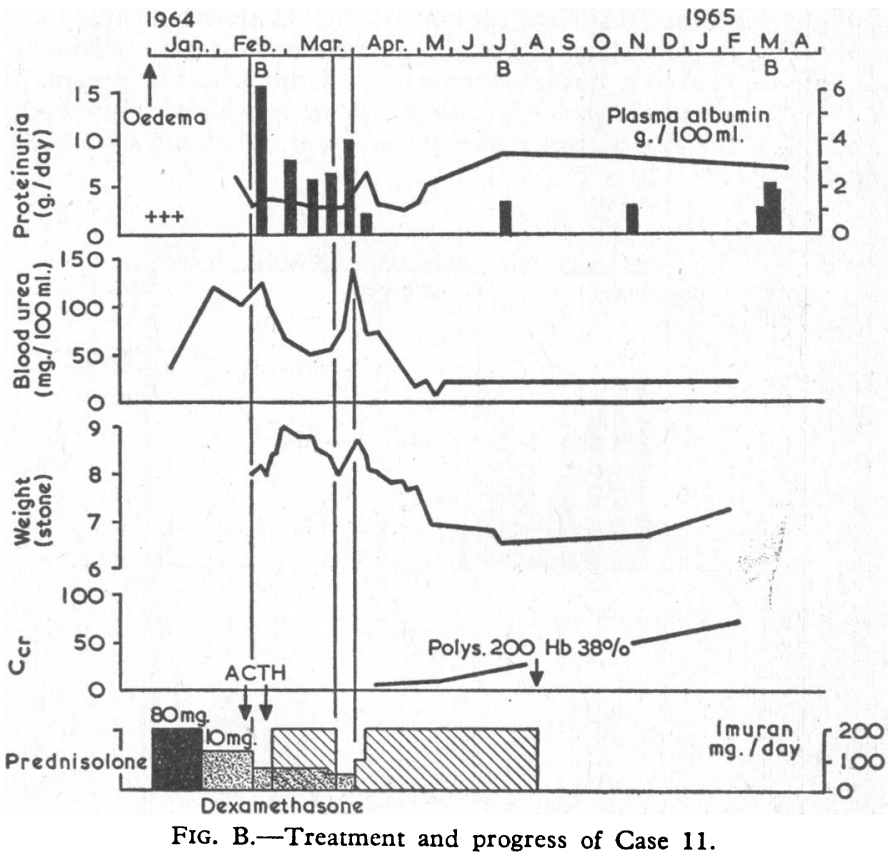

of proteinuria and a slight diuresis. However, after three weeks' treatment she developed a purpuric eruption and azathioprine treatment was stopped. Ten days later she suffered an acute exacerbation, with pulmonary oedema and a rapidly rising blood urea level. The resumption of azathioprine therapy was again followed by clinical and biochemical improvement. In the second biopsy (Special Plate, Fig. 5), after five months' treatment, some glomeruli showed partial or complete sclerosis, but the endothelial proliferation was generally less intense. However, widespread interstitial oedema and cellular infiltration were present.

Treatment was discontinued a month later owing to the development of leucopenia, anaemia, and vomiting. She remained well, however, and was able to resume normal school life, with symptomless proteinuria. Her creatinine clearance showed substantial improvement. The third biopsy, seven months after the end of azathioprine treatment, showed partial or complete sclerosis of half the glomeruli. However, unhyalinized glomeruli (Special Plate, Fig. 6) showed considerable resolution of both endothelial proliferation and capillary-wall thickening. 
Comment.-It appears that azathioprine twice resulted in definite improvement of renal function in a child who was extremely ill and in danger of dying from renal failure. However, it failed to prevent the development of a significant amount of glomerular scarring. Treatment would have been continued had not late toxic signs developed.

\section{Case 16}

A man aged 26 was admitted to Guy's Hospital with anuria five days after onset of acute nephritis. preceded by a sore throat. The antistreptolysin-O titre was raised and the renal biopsy (Special Plate, Fig. 9) showed severe endothelial proliferation, with polymorphonuclear exudation, capillary-wall thickening, extensive adhesions, and huge occluding crescents in all the glomeruli. Treatment with azathioprine, $4 \mathrm{mg} . / \mathrm{kg}$./day, was started and life was maintained by peritoneal dialysis until, despite the severity of the renal lesion, a diuresis occurred (Fig. C). There was heavy proteinuria, the serum albumin fell, and gross oedema developed. A further biopsy (Special Plate, Fig. 10) after four weeks' treatment showed that, although the glomeruli were less hypercellular, the tufts were becoming scarred and the enveloping crescents organized by collagen fibrils. After the addition of prednisolone to the treatment there was slight reduction of oedema and a rise in serum albumin, while the creatinine clearance very slowly improved. A third biopsy (Special Plate, Fig. 11) after six months' treatment showed extensive glomerulosclerosis with tubular atrophy and interstitial inflammation and fibrosis. It appeared that treatment had not prevented the destruction of glomeruli, and it was accordingly discontinued. Only retrospectively did it become evident that from this time his renal function slowly deteriorated, and when he subsequently became oliguric and uraemic again he did not respond to a further three weeks' azathioprine and prednisolone therapy and dialysis. Permission for necropsy was refused but was given for the post-mortem removal of renal tissue by biopsy needle (Special Plate, Fig. 12).

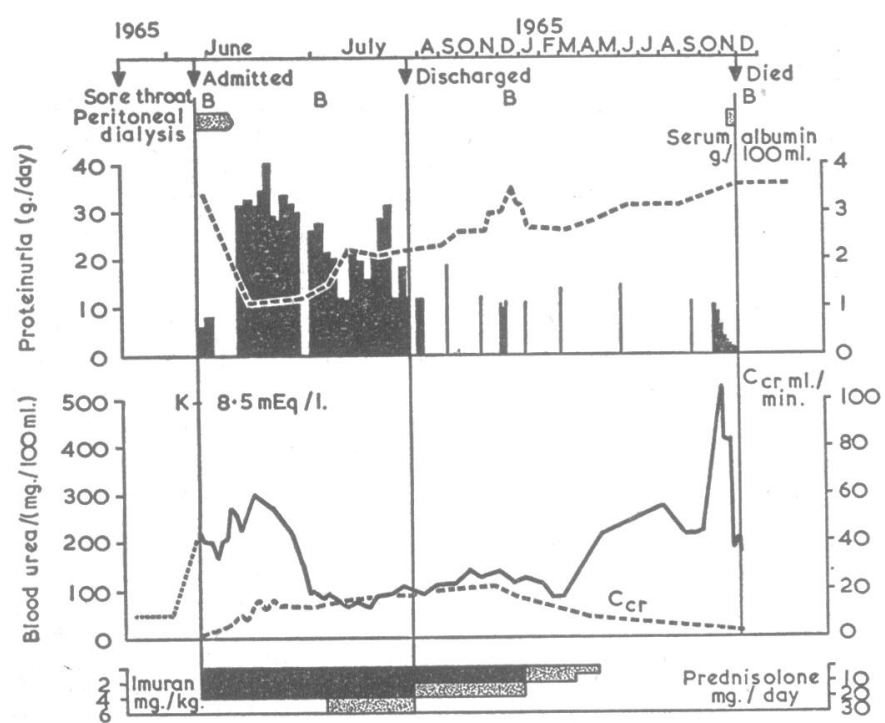

FIG. C.-Treatment and progress of Case 16.

Comment.-Harrison et al. (1964) and Berlyne and Baker (1964) have drawn attention to the generally fatal outcome in severe proliferative glomerulonephritis with occluding crescents. It seems probable that life was prolonged by the combined steroid-azathioprine therapy, and that deterioration followed the discontinuation of treatment.

\section{Discussion}

Most of the patients in this small series were severely ill, their nephrotic syndrome often being accompanied by haematuria, hypertension, and signs of renal insufficiency. Seven also had anaphylactoid purpura, and our findings are in agree- ment with those of Lagrue et al. (1962) that the complication of this disease by the nephrotic syndrome is nearly always an indication of severe disease, unlikely to respond to steroids. Since the clinical course of patients with severe proliferative glomerulonephritis is often one of progressive deterioration, with death from renal failure in a matter of months or a few years from onset, they present a considerable therapeutic challenge.

Corticosteroids, used in conventional dosage, not only failed to benefit the majority of our patients but actually harmed several. Five developed signs of increasing renal functional impairment, while one developed steroid diabetes, and two died -one from acute cerebral oedema and another from massive gastric haemorrhage-as a probable result of recognized complications of steroid therapy. We therefore urge great caution in the use of steroids in treating patients with the nephrotic syndrome complicated by macroscopic haematuria, hypertension, and raised blood urea levels, since these are the main clinical characteristics of severe proliferative glomerulonephritis.

While it generally follows that the outcome is unfavourable in patients with severe proliferative glomerulonephritis and favourable in those with milder lesions, the relation between structural alterations and functional defects is not a simple one. The death of two patients (Cases 1 and 18) and the persistence of symptoms and urinary abnormalities in three patients (Cases 2-4), all having relatively mild lobular-stalk proliferation, are not readily explained, although a fatal outcome was anticipated in one patient (Case 1) who had congenital nephrosis. Insufficient is yet known about the natural history of the various glomerular lesions we have observed, since the majority of nephrotic patients are nowadays treated with corticosteroids soon after onset.

These factors necessarily introduce difficulties in interpreting an apparently good response to therapy. Nevertheless, immunosuppressant drugs appeared to change the course of the illness in 12 patients, resulting in clinical recovery in three children and substantial improvement in most of the others. We are unable to explain why the children appeared to respond to treatment better than the adults. It is possible that the good results achieved in Cases 8 and 12, both of which patients had anaphylactoid purpura and severe proliferative glomerulonephritis with crescents, is related partly at least to the early recognition of steroid resistance and the prompt change of treatment.

It is thus appropriate to consider in detail the available diagnostic methods by which steroid failure can be predicted. We have already referred to the significance of accompanying haematuria, hypertension, and renal insufficiency, although these are not invariably present in patients who become steroidresistant. An adequate renal biopsy specimen is generally a reliable guide to the severity of the lesion, although steroidresistant nephrotics do not always have severe proliferative glomerulonephritis. In Cases $1-4$ and 18 in this series proliferation was not diffuse and crescents were absent. Although of immense value in an investigation of this kind, renal biopsy demands experience in pathological interpretation as well as technical skill, and this limits it to a number of centres with a major commitment to renal disease (Black and White, 1965 ; Lancet, 1965).

Determination of the selectivity of proteinuria is comparatively simple. There seems to be a good correlation between the selectivity and the severity of the renal lesion, as seen in renal biopsy specimens in both adults (Hardwicke and Soothill, 1961 ; Hitzig et al., 1965) and children (Cameron and White, 1965 ) with the nephrotic syndrome. Highly selective proteinuria is generally associated with a good steroid response, while unselective proteinuria invariably signifies a poor response (Joachim et al., 1964 ; Cameron, 1966). There are, however, exceptions to this rule, as Tables II and V show ; a minority of patients with highly selective proteinuria appear to be steroid-resistant, as in Cases $2-4$ of the present series. Of 94 
R. H. R. WHITE ET $A L .:$ STEROID-RESISTANT PROLIFERATIVE GLOMERULONEPHRITIS

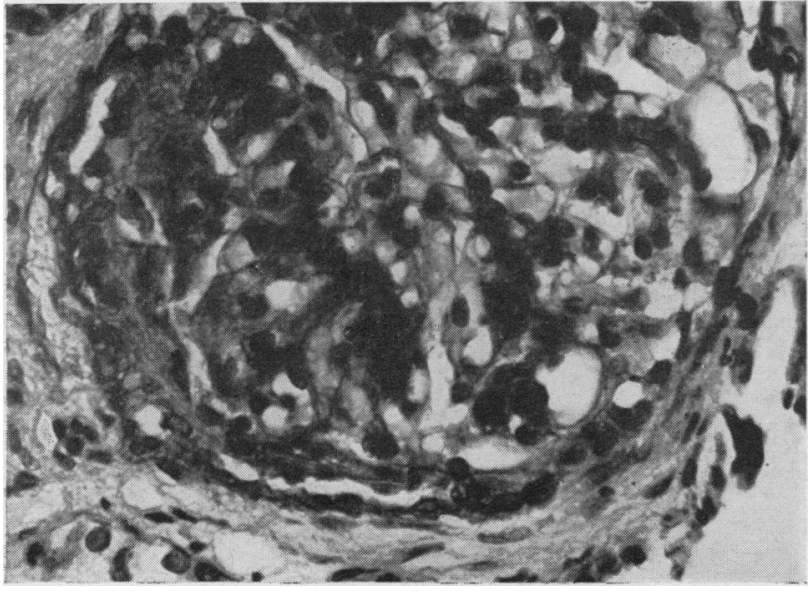

Fig. 1.-Case 12, first biopsy. Representative glomerulus showing endothelial proliferation and extensive adhesion to an epithelial

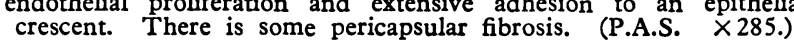

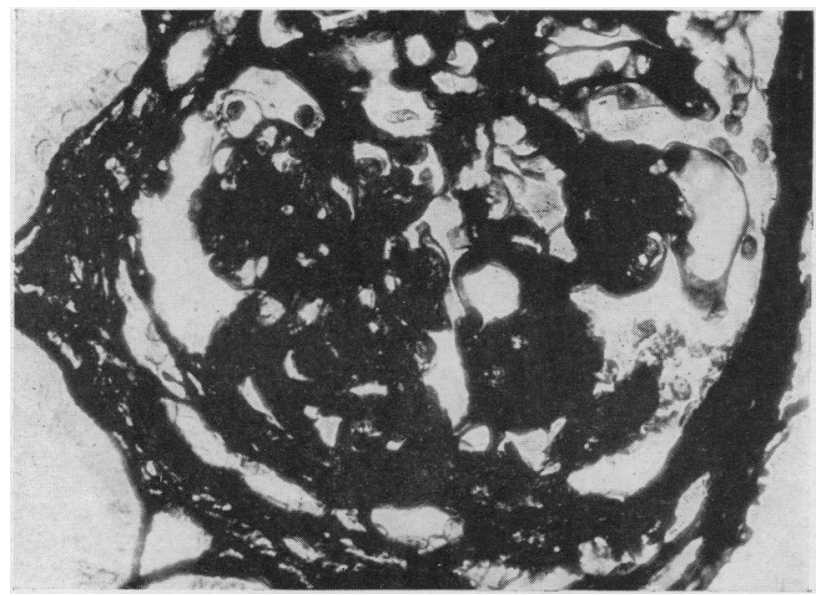

FIG. 2.- Case 12, first biopsy. The same glomerulus as that illustrated in Fig. 1, showing severe lobular-stalk thickening owing to dense fibrillar deposits, and variable argyrophilic capillary-wall thickening. Some of the capillary basement membranes on the right appear unaffected. (P.A.S.M. $\times 285$.)

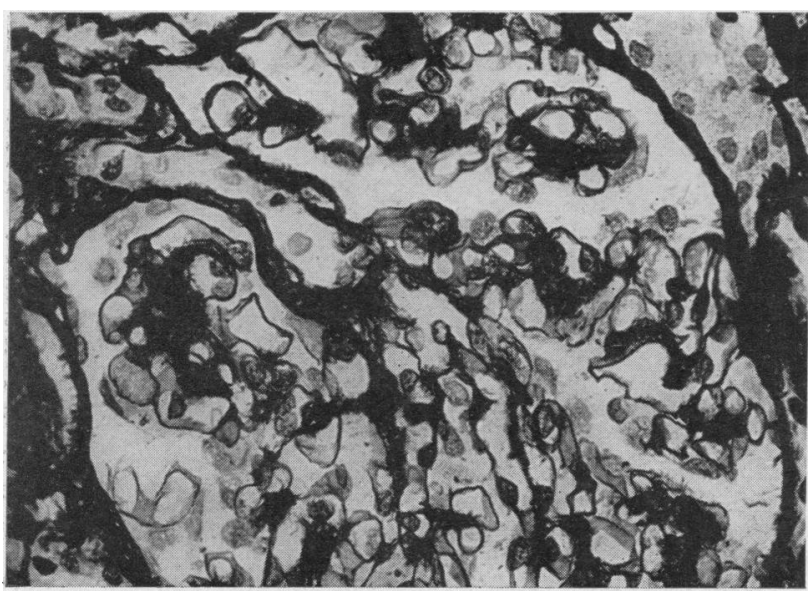

FIG. 3.-Case 12, second biopsy, after 34 weeks' cyclophosphamide treatment. A few glomeruli were sclerosed but the one illustrated represents the majority. Endothelial proliferation and mesangial fibrillar deposits are minimal, and the capillary basement membranes are normal. (P.A.S.M. $\times 285$.)

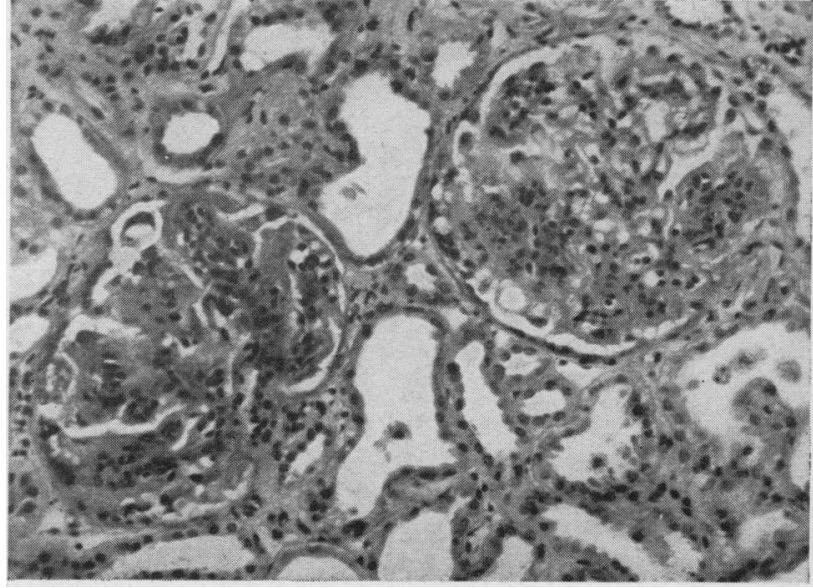

Fig. 4.-Case 11, first biopsy. Two glomeruli, showing severe endothelial proliferation and extensive adhesions to the proliferating capsular epithelium. About $70 \%$ of the glomeruli contained crescents. The capillary walls are greatly thickened with nonargyrophilic material, similar to that shown in Fig. 8 from Case 10 (P.A.S. $\times 180$.)

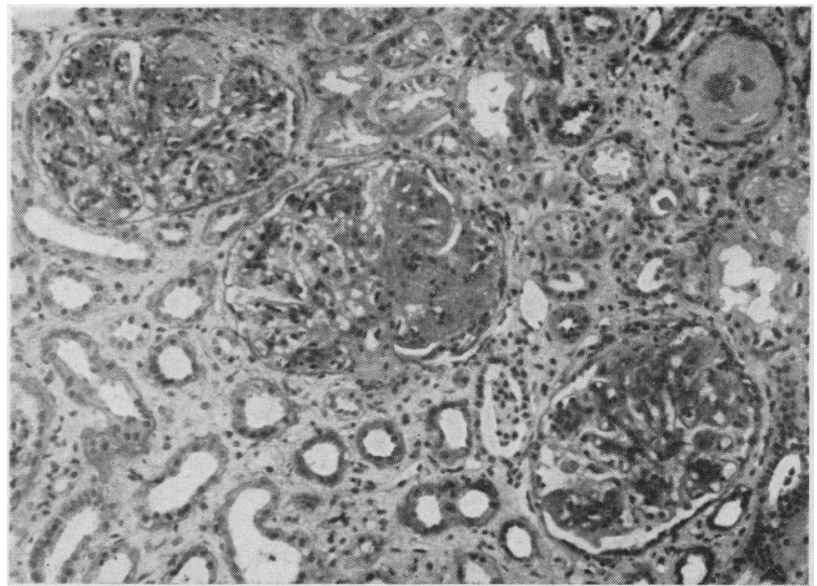

Fig. 5.-Case 11, second biopsy, after 22 weeks' azathioprine treatment (Fig. B in text). One glomerulus (top right) is completely sclerosed, while the others show localized hyalinization and adhesions. The endothelial proliferation, however, is less striking, and is confined to the lobular stalks. There is widespread interstitial oedema and round-cell infiltration, and focal tubular atrophy. (P.A.S. $\times 110$.)

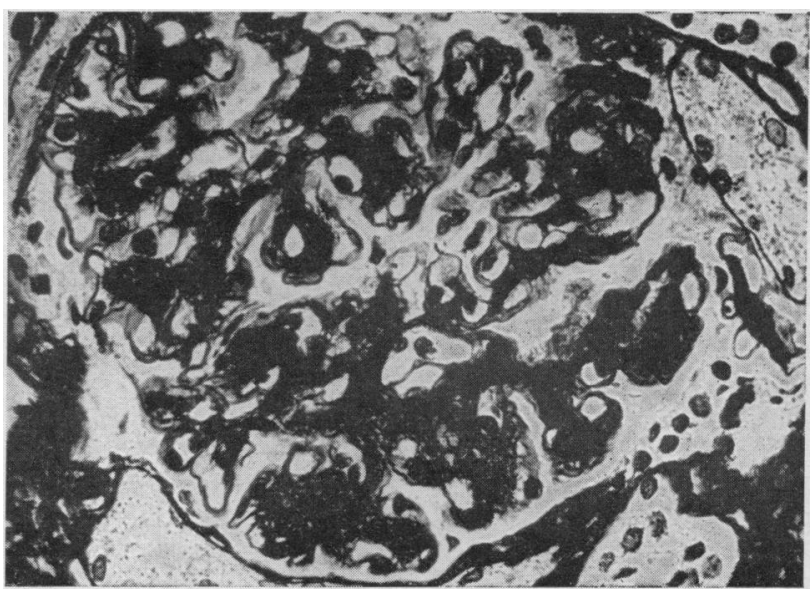

Frg. 6-Case 11, third biopsy, 29 weeks after cessation of treatment. Endothelial proliferation in unhyalinized glomeruli is mild and affects only the lobular stalks, which are thickened owing to fibrillar deposits. Some of the capillary basement membranes contain concentric, argyrophylic deposits on their endothelial surfaces. About half the glomeruli were completely sclerosed. (P.A.S.M. $\times 445$.) 
R. H. R. WHITE ET AL.: STEROID-RESISTANT PROLIFERATIVE GLOMERULONEPHRITIS

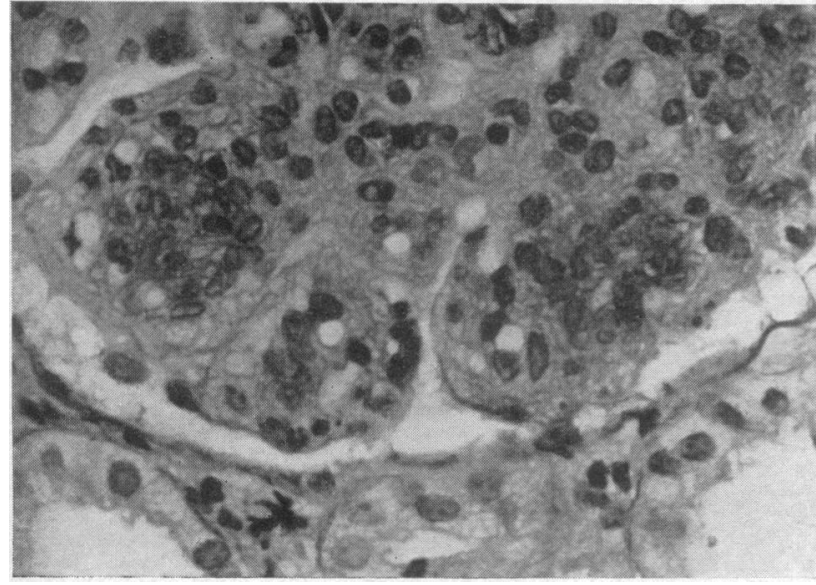

FIG. 7.-Case 10. Part of a swollen glomerulus, showing extreme endothelial proliferation, fibrillar mesangial deposits, and capillary wall thickening. The tuft also contains a number of polymorphonuclear leucocytes. All the glomeruli in the specimen were similarly affected. (P.A.S. $\times 480$.)

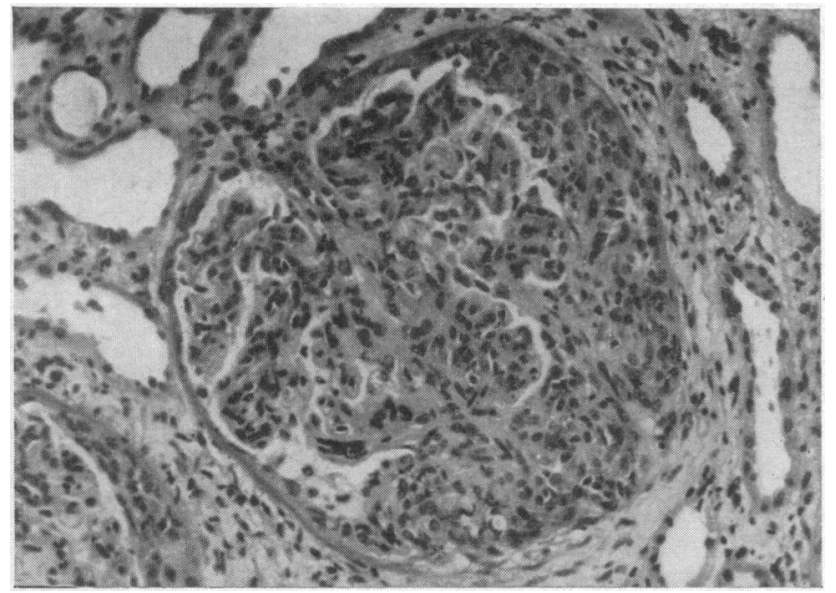

FIG. 9.-Case 16, first biopsy. This glomerulus shows severe endothelial proliferation and polymorphonuclear exudation and is surrounded by a huge epithelial crescent. All the glomeruli in the specimen were equally involved. There is also interstitial oedema and cellular infiltration. (P.A.S. $\times 180$.)

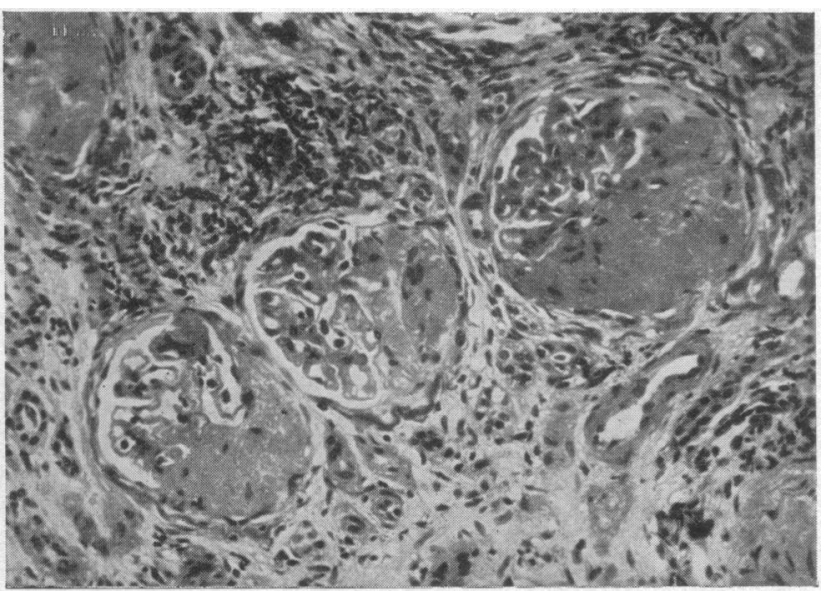

FIg. 11-Case 16, third biopsy, after a further 21 weeks' treatment with azathioprine and prednisolone. The glomeruli are extensively hyalinized. The capillary walls show thickening with silverpositive material Note the difference in size compared with glomeruli in the first two biopsies (Figs. 9 and 10), shown here at the same magnification. There are widespread interstitial and tubular changes. (P.A.S. $\times 180$.)

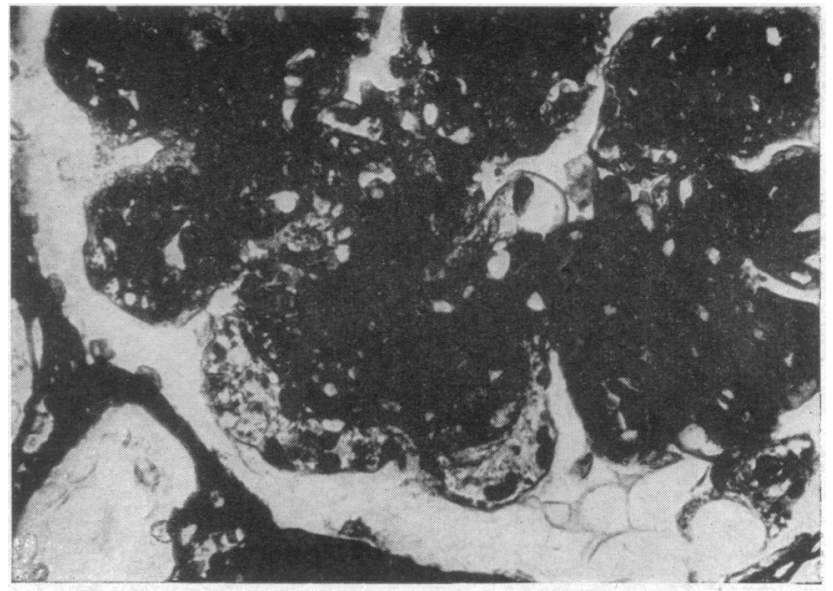

FIG. 8.-Case 10. Silver impregnation emphasizes the lobulation of the tuft and the extensive fibrillar deposits in the lobular stalks. The peripheral basement membranes are thin, stain poorly, and in places appear frasmented, while the material within them, accluding the capiliary lumina, is predominantly non-argyrophilic. (P.A.S.M. $\times 445$.)

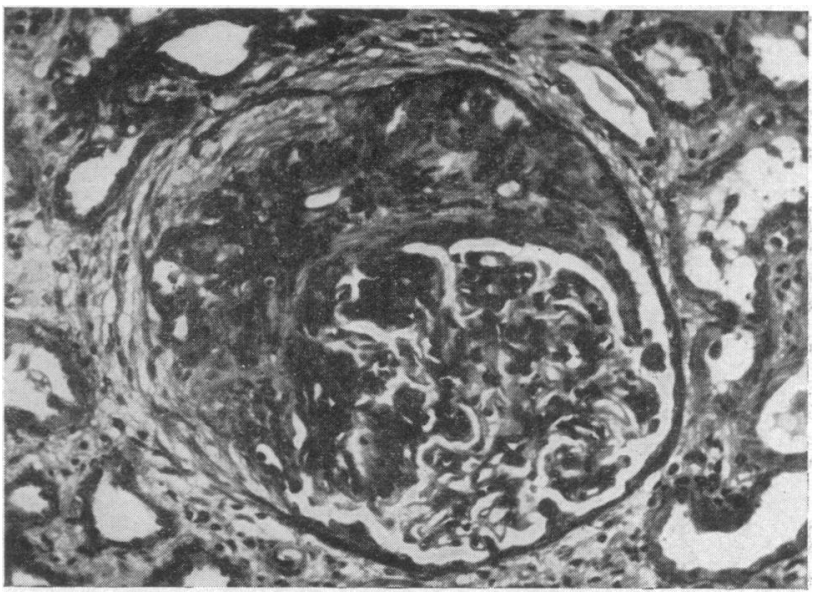

FIG. 10.-Case 16, second biopsy, after four weeks' azathioprine therapy (Fig. $C$ in text). Cellular proliferation is subsiding but the lobular stalks are thickened by fibrillar deposits and the crescent is becoming infiltrated with collagen. (P.A.S. $\times 180$.)

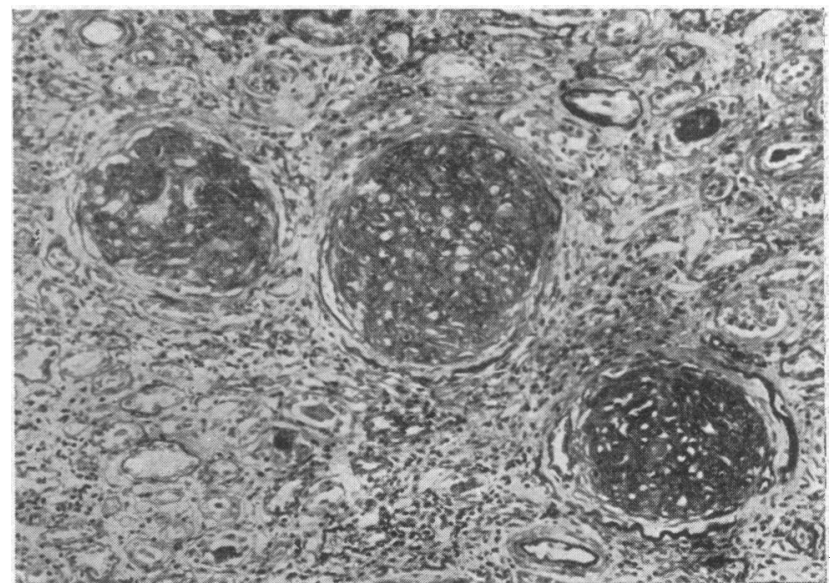

FIG. 12.-Case 16, necropsy, 50 weeks after the third biopsy and 30 weeks after cessation of treatment. All the glomeruli are sclerosed and most of the tubules atrophic. There is extensive: cellular infiltration and fibrosis. (P.A.S. $\times 118$. 
nephrotic children and adults studied by us, with data available on the response to an initial course of treatment, 37 showed poorly selective proteinuria, the angle being less than 60 degrees. Only one of these 37, an 11-year-old boy, lost his proteinuria, the angle in his case being 59.8 degrees. Methods currently in use (Soothill, 1962 ; Hardwicke, 1965b) are time-consuming, comparatively expensive, and thus suitable only for specialist laboratories. A newer, simplified technique has been developed which appears to give good correlations with the earlier methods (Cameron and Blandford, 1966), and should bring the investigation within the range of routine laboratory practice.

It is possible to demonstrate the presence of gamma-globulin and of complement components-for example, beta-1C-globulin -in diseased glomeruli, by immunofluorescent techniques, but they have been found in a variety of disorders in which glomeruli are involved (Michael et al., 1964), and their prognostic value is somewhat uncertain. More recently, however, Gotoff et al. (1965) and West et al. (1965a) have demonstrated persistently low levels of beta-1C-globulin in the serum of patients with chronic and progressive proliferative glomerulonephritis. West et al. (1965b) achieved remarkable improvement in one out of four children with persistent "hypocomplementaemic" glomerulonephritis by giving cyclophosphamide in combination with prednisone. We did not carry out serum total complement or beta-1C-globulin estimations, but five patients had histological features in their renal biopsy specimens (Special Plate, Fig. 8) similar to those described by West et al. (1965a) in "hypocomplementaemic" patients.

At the present time it appears that renal biopsy and determination of the selectivity of proteinuria jointly offer the best means of predicting steroid response. It is now our policy to use immunosuppressive therapy from the beginning, without first embarking on a trial of corticosteroids, in patients with proliferative glomerulonephritis showing persistent heavy proteinuria with poor selectivity (Cameron and Blandford, 1966), especially when accompanied by anaphylactoid purpura.

The actions of immunosuppressant drugs have recently been reviewed by Berenbaum (1964). Azathioprine is a purine antagonist, while cyclophosphamide releases a nitrogen-mustard-like chromosomal poison. It is theoretically possible that the proliferating endothelial and epithelial cells in diseased glomeruli are directly affected by a local cytotoxic action, as in the case of malignant neoplasms. On the other hand, the fixation of antibodies in diseased glomeruli and the depression of serum complement components suggest-but do not prove-that immune mechanisms play a part in the evolution of the disease, and it seems reasonable to suppose that in successful cases the proliferative reaction is halted by suppression of antibody production. This view is also supported by the recent experimental observations of Russell et al. (1966), who were able to retard the development of lethal glomerulonephritis in strains of mice with a high incidence of the disease, by pretreating them with cyclophosphamide. On the basis of immunofluorescent studies McCluskey et al. (1966) have suggested that other mechanisms, such as fibrin deposition, may also operate. The use of these drugs must for the time being be regarded as empirical, and we do not yet possess any logical basis on which to select a particular drug for an individual patient.

All the drugs used have notable side-effects, which are largely dose-dependent. The doses used in this study were generally high, and in the range where bone-marrow depression would be anticipated. Like Shearn (1965), who treated patients similar to ours with mercaptopurine, we had initially believed that the production of leucopenia should be the aim if suppression of antibody production was to be expected. In fact all but two of the children who improved developed leucopenia, although in most cases it was a late toxic sign and occurred after signs of improvement were already evident. On the whole, sideeffects were more prominent in patients treated with azathioprine than with cyclophosphamide, and treatment had to be discontinued in Cases 5, 9, and 11, who were all improving, because of the development of anaemia, leucopenia, and vomiting. In Cases 2 (Fig. A) and 4 azathioprine was also stopped when the blood leucocyte count started falling, and considerable anxiety was caused by the continued decline, leading to agranulocytosis, which persisted for a week in each case.

Fortunately, all the toxic effects observed were reversible. We have noticed that in several recently treated patients not included in this paper the addition of prednisolone to immunosuppressant agents has resulted in a rise of the white blood cell count. John (1966) has reported a leucocytosis persisting throughout therapy in 10 children receiving steroids for nonhaematological disorders, and regards this phenomenon as a specific effect.

We believe that the results reported here are sufficiently encouraging to warrant further controlled studies, and we are currently attempting to answer the question whether combined treatment with smaller doses of immunosuppressant agents and steroids is more effective and less toxic than either drug alone.

\section{Summary and Conclusions}

The results of immunosuppressive therapy are described in 13 children and five adults suffering from proliferative glomerulonephritis, shown by renal biopsy to be severe in 13 patients. Azathioprine was used in 13 and cyclophosphamide in five. Sixteen were nephrotic at the beginning of treatment and two had previously had nephrotic episodes. Seven also had anaphylactoid purpura. Fifteen patients had previously been unsuccessfully treated with high doses of corticosteroids, the dangers of which are emphasized.

Three children died after two days' to five weeks' treatment ; one was a congenital nephrotic, and two died as a result of probable steroid complications. The remainder improved clinically and biochemically, three losing their proteinuria completely. One child relapsed after cessation of treatment.

One adult died of renal failure after only 10 days' treatment. Two of the remaining four showed benefit when prednisolone was combined with azathioprine, but one of these subsequently died of renal failure after treatment had been discontinued.

Toxic effects, notably the results of bone-marrow depression, were seen in six patients receiving azathioprine, two of whom developed transient agranulocytosis. Moderate alopecia was temporarily observed in patients treated with cyclophosphamide.

The renal histology and the characteristics of the proteinuria are described; the role of renal biopsy and of determination of the selectivity of proteinuria in predicting steroid resistance are discussed.

We wish to thank our colleagues at Guy's Hospital and the many other paediatricians and physicians who have referred patients to us for investigation and treatment. The renal biopsy sections were prepared by Mr. G. H. Osborn and Miss Janet Harwood.

\section{REFERENCES}

Arneil, G. C. (1961). Lancet, 2, 1103.

Berenbaum, M. C. (1965). Brit. med. Bull., 21, 140.

Berlyne, G. M., and Baker, S. B. de C. (1964). Quart. 7. Med., 33, 105. Berlyne, G. M., and Baker, S. B. de C. (1964). Quart. F. Med., 33, 105. Paediatrics, edited by D. Gairdner, 3rd ed., p. 307. Churchill, London.

Blainey, J. D., Brewer, D. B., Hardwicke, J., and Soothill, J. F. (1960) Quart. F. Med., 29, 235.

Cameron, J. S. (1966). Proc. roy. Soc. Med., 59, 512. and Blandford, G. (1966). Lancet, 2, 242.

and White, R. H. R. (1965). Ibid., 1, 463.

Chasis, H., Goldring, W. H., and Baldwin, D. S. (1949). Proc. Soc. exp. Biol. (N.Y.), 71, 565 .

(1950). F. clin. Invest., 29, 804

Cheng Siang, S., Wong, K. H., Chew, A. G. K., and Jayaratnam, F. J. (1966). Brit. med. 'F., 1, 333.

Coldbeck, J. H. (1963). Mied. Ұ. Aust., 2, 987. 
Demis, D. J., Brown, C. S., and Crosby, W. H. (1964). Amer. J. Med., 37, 195.

(196nd, K. N., Michael, A. F., Good, R. A., and Vernier, R. L. (1964), 7. Pediat., 65, 1114.

iles, H. MCC., Pugh, R. C. B., Darmady, E. M., Stranack, F., and Woolf, L. I. (1957). Arch. Dis. Childh, 32, 167.

Goodman, H. C., Wolff, S. M., Carpenter, R. R.; Andersen, B. R., Brandriss, M. W. (1963). Ann. intern. Med., 59, 388.

Gotoff, S. P., Fellers, F. X., Vawter, G. F., Janeway, C. A., and Rosen, F. S. (1965). New Engl. ₹. Med., 273, 524. Greenman, L., Weigand, F. A., and Danowski, T. S. (1955). Amor. F.

Haggerty, R. J., Maroney, M. W., and Nadas, A. S. (1956). Ibid., 92, 535.

Hardwicke, J. (1965a). 7. clin. Path., 18, 559.

(1965b). Clin. chim. Acta, 12, 89.

- and Soothill, J. F. (1961). In Ciba Foundation Symposium on Renal Biopsy, edited by G. E. W. Wolstenholme, and M. P. Cameron, p. 32. Churchill, London.

Harrison, C. V., Loughridge, L. W., and Milne, M. D. (1964). Quart. 7. Med., 33, 39.

Hill, R. D., and Scott, G. W. (1964). Brit. med. F., 1, 370.

Hizzig, W. H., Auricchio, S., and Benninger, J. H." (1965). Klin. W schr., 43, 1154.

Joachim, G. J., Cameron, J. S., Schwartz, M., and Becker, E. L. (1964). 7. clin. Invest., 43, 2332 .

John, T. J. (1966). Amer. F. Dis. Child., 111, 68.

Keliey, V. C., and Panos, T. C. (1952). 尹. Pediat., 41, 505.

Kellum, R. E., and Haserick, J. R. (1963). Arch. Derm., 87, 289.

Lagrue, G., Bariety, J., de Kérautem, Y., Samarca, P., Fritel, D., de Boisdeffre, B., and Milliez, P. (1964)." F. Urol. Néphrol., 70, 156.
Fritel, D., Tcherdakoff, P. G., Bariety, J., Samarcq, P., and Milliez, P. (1962). Sem. Hôp. Paris, 38, 425.

Lancet, 1965, 2, 473 .

Lestina, F. A., Freedman, S., and Wilson, H. (1953). 7. Lab. clin. Med., 42, 918 .

McClusky, R. T., Vassali, P., Gallo, G., and Bald'win, D. S. (1966). N. Engl. F. Med., 274, 696 .

Michael, A. F., Drummond, K. N., Vernier, R. L., and Good, R. A. (1964). Pediat. clin. N. Amer., 11, 685.

Milliez, P., Lagrue, G., and Bariety, J. (1965). Bull. Acad. nat. Med. (Paris), 149, 259.

Payet, M., Sankale, E., Moulanier, M., and Diop, B. (1964). Thérapie, $19,921$.

Pearl, M. A., Burch, R. R., Carvajal, E., McCracken, B. H., Woody, H. B., and Sternberg, W. H. (1963). Arch. intern. Med., 112, 716 .

Peters, J. H. (1963). In Biochemical Clinics No. 2: The Kidney,

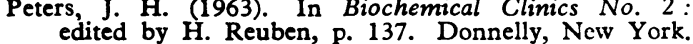

Riley, C. M., and Scaglione, P. R. (1959). Pediatrics, 23, 561.

Russell, P. J., Hicks, J. D., and Burnet, F. M. (1966). Lancet, 1, 1279.

Saxena, K. M., and Crawford, J. D. (1965). Amer. Heart 7., 70, 835.

Shearn, M. A. (1965). New Engl. F. Med., 273, 943.

Soothill, J. F. (1962). F. Lab. clin. Med., 59, 859.

Talamo, R. C., and Crawford, J. D. (1963). New Eng!. 7. Med., 269, 15. Taylor, R., Corcoran, A. C., and Page, I. H. (1950). F. Lab. clin. Med.,

36, 996. (1958). Amer. F. Dis. Child., 95, 498.

West, C. D. (1958). Amer. F. Dis. Child., 95, 498. N. H. (1965a). F., Pediat., 67, 1089 .

Holland, N. H., McConville, J. M., and McAdams, A. J. (1965b). Ibid., 67, 1113.

Hong, R., and Holland, N. H. (1966). Ibid., 68, 516

White, R. H. R. (1963). Arch. Dis. Childh., 38, 260.

\title{
Tetanus in Childhood: Report of a Therapeutic Trial of Diazepam
}

\author{
R. G. HENDRICKSE,* M.D., F.R.C.P.ED. ; P. M. SHERMAN, $\dagger$ M.B., B.S., D.C.H.
}

Brit.med. F., 1956, 2, 860-862

The clinical management of tetanus poses a difficult therapeutic problem to physicians everywhere. Mortality from the disease remains high even in those medical centres endowed with the best facilities currently available. In many developing countries where the disease is prevalent, and medical services are inadequate for local needs, mortality figures are alarmingly high, especially among cases of neonatal tetanus (Tompkins, 1958 ; Loh Siew Gek, 1951). In these circumstances any innovation in treatment that offers some hope of reducing mortality from the disease is worthy of trial, especially if it is simple, relatively inexpensive, and safe.

Diazepam (Valium) has two distinct pharmacological properties-tranquillizing and muscle-relaxant. In experimental work the drug has been shown to block spinal reflexes in anaesthetized cats (Randall et al., 1961), and it has been used with benefit in the management of the "stiff-man syndrome," which previously was unamenable to any form of treatment (Howard, 1963). These facts suggested that diazepam might be of value in the management of tetanus, and in October 1964 a therapeutic trial was started. Preliminary findings were encouraging (Hendrickse and Sherman, 1965). The trial has since been completed, and this report summarizes our findings.

\section{Material and Methods}

When the trial started in October 1964 all new cases of tetanus seen in the Department of Paediatrics were randomly allocated into one of three treatment groups designated $A, B$, and $C$.

The following standard treatment was given to all groups: (1) paraldehyde by intramuscular injection for immediate con-

\footnotetext{
* Professor and Head of Department of Paediatrics, University College Hospital. Ibadan. + Research Fellow
}

trol of spasms ; (2) anti-tetanus serum, 20,000 to 50,000 units, by intramuscular injection; (3) penicillin, 150,000-300,000 units daily, for five days ; (4) as soon as initial sedation was secured with paraldehyde a gastric tube was passed through the nose, and subsequent medication was administered by this route during the early days of treatment ; and (5) additional antibiotics-for example, tetracycline-were used for complications such as bronchopneumonia.

The following regimens of sedation were then employcd in the different groups:

Group A: Phenobarbitone, 4.4-6.6 mg. $/ \mathrm{kg}$., and chlorpromazine 1.1-2.2 mg. $/ \mathrm{kg}$. six-hourly.

Group B: Phenobarbitone and chlorpromazine as in group A, plus diazepam, 0.44-1.1 mg. $/ \mathrm{kg}$. six-hourly.

Group C: Diazepam only; up to $1.1 \mathrm{mg} . / \mathrm{kg}$. six-hourly.

The clinical course of all patients was recorded on a special form. The data recorded were summarized at the end of each 24-hour period, and sedation was modified, if necessary, in the light of the patient's progress. Routine administration of phenobarbitone, chlorpromazine, and diazepam was by the nasal tube, injections being given only where specially indicated.

Following our observations on the first 26 cases admitted to the trial that diazepam on its own appeared to be not very effective in controlling convulsive spasms during the early phase of treatment, it was decided to eliminate group C. From March 1965, therefore, cases were randomly allocated into groups A and B only.

Between October 1964 and October 1965199 childien under 10 years of age were admitted with the diagnosis of tetanus. Of this number 149 are included in this report. The 50 patients who have been excluded are those who (a) were seen during three brief periods when the trial was temporarily suspended, or (b) fell into our original Group C, or (c) could not be validly assessed either because their records were incomplete 